\title{
A Review on Pulp Manufacture from Non Wood Plant Materials
}

\author{
Kamoga Omar Lwako M., Byaruhanga Joseph K., and Kirabira John Baptist
}

\begin{abstract}
There has been a cyclic trend in the production of pulp and paper, alternating between the non-wood and the wood materials. Originally paper wasbeing made from nonwood materials such as papyrus, hemp and textile rags. With the development of technologies for isolating pulp from wood, it resulted in abandoning paper making from many non-wood materials. Since then, it has been cheaper to produce pulp and paper from wood. However, todate the trend is reversing from wood as the major source of pulp for paper making to nonwood materials such as agricultural food crop residues, grasses, shed tree leaves, fibrous shells of fruits and others. This is due to the fact that the supply of wood for pulp is decreasing as a result of deforestation in most part of world, more especially in Uganda while the non-wood materials are more available and can readily be regenerated after a short period.In this paper we have reviewed the trend in pulp and paper production from different non-wood materials since the perception of the paper making technology up todate through literature review and consultations with experts in the area pulp and paper production.
\end{abstract}

Index Terms - Non-wood materials, pulp and paper, Uganda, waste grass

\section{INTRODUCTION}

The demand and use of pulp and paper have marked the levels of civilization and development of many societies. As a result many developed nations use plenty of pulp and paper. The demand for pulp and paper fiber resources is largely determined by the society's dependence on paper, paper boards and other related products for human welfare. The pulp in society is used in education, information storage, advertising, communication, in protection, transportation and security of goods in transit; protection of human health and sanitation in form of tissues and sanitary paper products. Paper making process for long has mainly used wood from tree stems that are cut, debarked, chipped and pulped.

It is interesting to note that some environment advocates have proposed the use of non-wood fibers in paper making as a way to preserve natural forests.

Both wood and non-wood resources are currently exploited for the manufacturing of pulp, paper and soft boards.

But still the major source of pulp which meets more than $80 \%$ demand is still wood from forests. However scientists

Manuscript received March 14, 2013; revised May 15, 2013. The work was financed the Swedish International Development Agency (SIDA).

The authors are with the Department of Mechanical Engineering, College of engineering Design, Art and Technology, Makerere University (e-mail: $\quad$ kamogaol@yahoo.co.uk, jbyaruhanga@tech.mak.ac.ug jbkirabira@tech.mak.ac.ug). all over the world in the last two decade have been involved in intensive research for the alternative sources of pulp for paper industry [1], [2].

As environment related climatic changes have become national and international challenges, possible sources of vital human needs, paper inclusive must be looked for from alternative extraordinary sources that offer less adverse impact on the environment.

In most cases the non-wood materials such as agricultural food cropresidues, grasses and tree leaves which do not have immediate beneficial applications in many communities have been proposed to be potential sources of pulp. Since all these plant materials contain cellulose in form of fibres, they stand to be potential sources for pulp manufacture with less environmental degradation threat. By isolating pulp from non-wood materials, it may reduce on the rate of clearing mature trees for pulp as well as reducing on the waste plant materials that tends to accumulate in towns and cities.

\section{A. Historical Trend of Pulp and Paper Manufacturing}

The principles of paper making from pulp were laid down in A.D. 105, when Ts'ai Lun of China macerated the bark of mulberry trees (Broussonetia papyrifera), dipped a silk screen mold into the dilute macerate and on withdraw formed the first sheet of paper [3] More than 600 years earlier, pressed sheets from papyrus were widely used in Egypt. However these sheets could not be considered to be paper, since they were composed of strips cemented together in a random fashion. Papyrus was very important to the ancient Egyptians as it transformed Egyptian society in many ways. Not only was this ancient Egypt's greatest export but it revolutionized the way people kept valuable information. Once the technology of papyrus paper making was developed, it was kept a secret, allowing the Egyptians to have a monopoly on it.

No substitute for papyrus paper could be found that was as durable and light weight until the development of the pulped paper by the Arabs in the $8^{\text {th }}$ century. Thereafter the process of making pulp paper was far easier butthe paper was not as durable as papyrus paper. This not only led to a decline in papyrus paper but also to a decline in papyrus plant cultivation. Papyrus paper making was not revived until around 1969 when an Egyptian scientist Dr. Hassan Ragabstarted a papyrus plantation near Cairo. He had to develop a new method of production because the ancient Egyptians left no written records as to the manufacturing process. Now papyrus paper making is back in Egypt [4].

The Chinese in the $2^{\text {nd }}$ century BC had a paper making process developed utilizing fibrous matter. Seventeen and a half centuries elapsed after Lun's demonstration, before wood became the accepted fiber source for paper[5]. Wiesner's investigations disclosed that the Chinese papers 
also contained fiber from hemp, flax and rags [6]

Even before the Chinese secret of paper making started to move westward, the Mayan Indians of Central America were using paper of their own manufacture. The importance of paper to the Mayan is indicated by its use as their commodity currency [7]. In many of these societies in the early days the use of cotton and linen rags in paper marking has been documented.

\section{B. Sources of Pulp and Their Compositions}

In many early societies such as the United States of America, China and Egypt, paper was traditionally made from non-wood materials, mainly from waste products from textile industries. Wood became the major fiber source for paper in mid 1800s [8]. Therefore its use as source of pulp for paper making is a fairly recent innovation. Hemp is probably one of the oldest plants cultivated for fiber; and its use as a fiber for paper dates back more than 2000 years [9]. The use of wood to make pulp for paper began with the development of mechanical pulping in Germany by F. G. Keller in 1840 [10].

Todate most pulp and paper industries obtain the cellulose pulp mainly from hard and soft wood. Of recent there has been a shift from natural forests as source of wood for pulp industries to artificial established forest plantations in order to keep in pace with the growing demand for pulp and paper.

Still with these forests in place, there is still a growing threat of insufficient wood supply and the growing demand for pulp and paper. This has prompted some industries to search for alternative non-wood crop fiber sources. The nonwood plant materials which have been tried so far for pulp production include cereal straws, sugarcane bagasse, bamboo, reeds, esparto, kenaf, corn stalks, sorghum stalk, etc. These have been used to produce shorter fibers which are substitutes to hardwood pulp. On the other handcotton staples and linters, flax, hemp, sisal, abaca, hesperaloe etc. have been used to produce longer fibers which are substitutes to the softwood pulp [11].

Both wood and the non-wood materials of plants consist of similar chemical constituents although in dissimilar magnitudes. For example plant leaves and grasses, like wood are renewable resources that are expected to contain cellulose, lignin, hemi-cellulose, some terpenes, resins, inorganic elements and fatty acids. The total cellulose content in some plant leaves and grass has been reported to have an average value of about 32.6 to $88 \%$ [12].

Cellulose is an organic compound with the formula $\left(\mathrm{C}_{6} \mathrm{H}_{10} \mathrm{O}_{5}\right)_{\mathrm{n}}$, a polysaccharide consisting of a linear chain of several hundreds to over ten thousand linked D- glucose units [13]. Cellulose is the structural component of the primary cell wall of green plants, many forms of algae and the oomycetes. Some species of bacteria secrete cellulose to form biofilms. Cellulose is the most common organic compound on earth, on average about 33 percent of all plant matter is cellulose and in cotton it is 90 percent while wood has an average of 50 percent [14]. Cellulose was discovered in 1838 by the French chemist Anselme Payen who isolated it from plant matter and determined its chemical formu [13] and [15]. Cellulose was used to produce the first successful thermoplastic polymer 'celluloid' by Hyatt manufacturing company in 1870. Hermann Staudinger determined the polymer structure of cellulose in 1920. The compound was first chemically synthesized in 1992 by Kobayashi and Shod [16].

TABLE. I: The Methods Used to Determine the Chemical COMPOSITION OF Plant MATERIALS FOR PULP AND PAPER MANUFACture

\begin{tabular}{|c|c|c|c|}
\hline & Constituents & $\begin{array}{l}\text { Common method(s) of } \\
\text { analysis }\end{array}$ & Brief description of the method \\
\hline (a) & Hollocellulose (Total Cellulose) & $\begin{array}{l}\text { Norman and Jenkin's } \\
\text { standard method }\end{array}$ & $\begin{array}{l}\text { During the analysis the dry ground raw material of } 40-60 \text { mesh is } \\
\text { prepared and extracted with alcohol-benzene combination. And then } \\
\text { known weights of the fibrous material are treated with a sequence of } \\
\text { the combination of hypochlorite and sulphite to remove other binding } \\
\text { materials. }\end{array}$ \\
\hline (b) & $\begin{array}{l}\text { Ethanol- Benzene } \\
\text { Extractives(comprised of some } \\
\text { terpenes, resins and fatty acids.) }\end{array}$ & $\begin{array}{l}\text { Standard Tappi method } \\
\text { T } 204 \text { om- } 88 .\end{array}$ & $\begin{array}{l}\text { This method involves the soxhlet extraction of the air dried plant } \\
\text { materials with a combination of ethanol and benzene at } 1: 2 \mathrm{v} / \mathrm{v} \text { for } \\
\text { about 8hours. }\end{array}$ \\
\hline (c) & $\begin{array}{l}1 \% \mathrm{NaOH} \text { Extractives (Low } \\
\text { molecular weight carbohydrates) }\end{array}$ & $\begin{array}{l}\text { Standard method T212 } \\
\text { om- } 88 .\end{array}$ & $\begin{array}{l}\text { The air dried raw materials are extracted with } 1 \% \text { of } \mathrm{NaOH} \text { solution } \\
\text { to remove and determine the low molecular weight carbohydrates. In } \\
\text { this method an appropriate mass of material will be treated with of } \\
\text { hot } \mathrm{NaOH} \text { solution }(1 \%) \text { for one hour, the extract is evaporated to } \\
\text { dryness and the residues determined gravimetrically }\end{array}$ \\
\hline (d) & Lignin & $\begin{array}{l}\text { Norman and Jenkins' } \\
\text { method }\end{array}$ & $\begin{array}{l}\text { By cold treatment of dry residues from the alcohol-benzene soxhlet } \\
\text { extraction with concentrated sulphuric acid. And lignin is } \\
\text { precipitated by refluxion in diluted acid and determined } \\
\text { gravimetrically. }\end{array}$ \\
\hline (e) & Ash Content & $\begin{array}{l}\text { TAPPI standard method } \\
\text { T } 211 \text { om-93 }\end{array}$ & $\begin{array}{l}\text { The ash content of the dried plant materials is analyzed by } \\
\text { combustion the materials at } 525^{\circ} \mathrm{C} \text { in a muffle furnace and then } \\
\text { determine gravimetrically. }\end{array}$ \\
\hline
\end{tabular}

Lignin is a complex chemical compound most commonly derived from wood and it is an integral part of the secondary cell walls of plants and some algae. The term lignin was introduced in 1819 by De Candolle and was derived from Latin word "lignum" meaning wood, it constitutes from a quarter to a third of the dry mass of wood. It fills the spaces in cell wall between cellulose, hemicellulose and pectin components and thereby crosslinks different plant polysaccharides conferring mechanical strength to the cell wall and by extension of the plant as a whole [17]. Thus lignin is indigestible by animal enzymes. Furthermore, because of its cross linking with the other cell wall 
components it minimizes the accessibility of cellulose and hemicellulose to microbial enzymes, therefore helps to defend against pathogens.

Plant materials in addition to the organic components also consist of various inorganic chemicals which contribute to what is referred to as the ash content of the isolated pulp. Ash is the residue left after igniting the dry materials to higher temperatures and it is reported in $\%$ of residue to dry material basis.

\section{CONSTITUENTS ANALYSIS}

It is always important to determine the composition of raw materials before they are processed, as to evaluate their feasibilities in production. The method and conditions of isolating pulp depend also on the composition of the raw material. The different methods commonly used in the constituent analysis of the plant materialsare outlined in the Table I.

\section{TECHNIQUES FOR ISOLATING PULP}

Cellulose in form of pulp is isolated from plant materials in a process known as pulping. The pulping techniques of the non-wood plant materials are the modified methods of those which have been used in wood pulping.

The pulping techniques can be categorized as mechanical, thermal, semi chemical or fully chemical methods. Chemical methods which have been developed in pulping include Kraft, sulfite, soda and organosolv pulping processes. Chemical pulping is achieved by degrading the lignin and hemicelluloses into small water soluble molecules which can be washed away from the cellulose fibres without depolymerizing the cellulose fibers.

The characteristic properties of the isolated pulp depend on the techniques of processing most especially the chemical method. The different chemical and bio-pulping methods that are commonly employed in pulping both wood and non-wood materials are given in Table II.

TABLE II: The Chemical PUlPING Methods Commonly Used

\begin{tabular}{|c|l|l|l|l|}
\hline & $\begin{array}{l}\text { Chemical pulping } \\
\text { Methods }\end{array}$ & Chemicals used & Properties of pulp isolated & Common uses of isolated pulp \\
\hline a & Sulphite & $\begin{array}{l}\text { Sulphurous acid/ sodium } \\
\text { sulphite }\end{array}$ & $\begin{array}{l}\text { High flexibility and requires very little } \\
\text { bleaching }\end{array}$ & Used in making paper for special purposes \\
b & Kraft/ Sulphate & $\begin{array}{l}\text { Combination sodium hydroxide } \\
\text { and sodium sulphide }\end{array}$ & Strong, low brightness(dark brown) & $\begin{array}{l}\text { Making boxes, paper bags and wrapping } \\
\text { paper. Can also be used for writing paper } \\
\text { and paperboard when bleached }\end{array}$ \\
\hline c & Soda & $\begin{array}{l}\text { Sodium hydroxide and } \\
\text { anthraquinone }\end{array}$ & $\begin{array}{l}\text { Have properties similar to those of } \\
\text { sulphite. }\end{array}$ & $\begin{array}{l}\text { Ideal for all paper uses } \\
\text { and evaluated }\end{array}$ \\
\hline d & Organosolv & Organic solvents e.g Ethanol & $\begin{array}{l}\text { Much of the properties arestill being tested } \\
\text { and other properties are still under } \\
\text { investigations }\end{array}$ & $\begin{array}{l}\text { Preliminary results suggest possible } \\
\text { application in all aspects of paper uses. }\end{array}$ \\
\hline e & Biopulping & $\begin{array}{l}\text { Involves the use of white } \\
\text { fungus K14 }\end{array}$ & & of paper[18] and [19]. \\
\hline
\end{tabular}

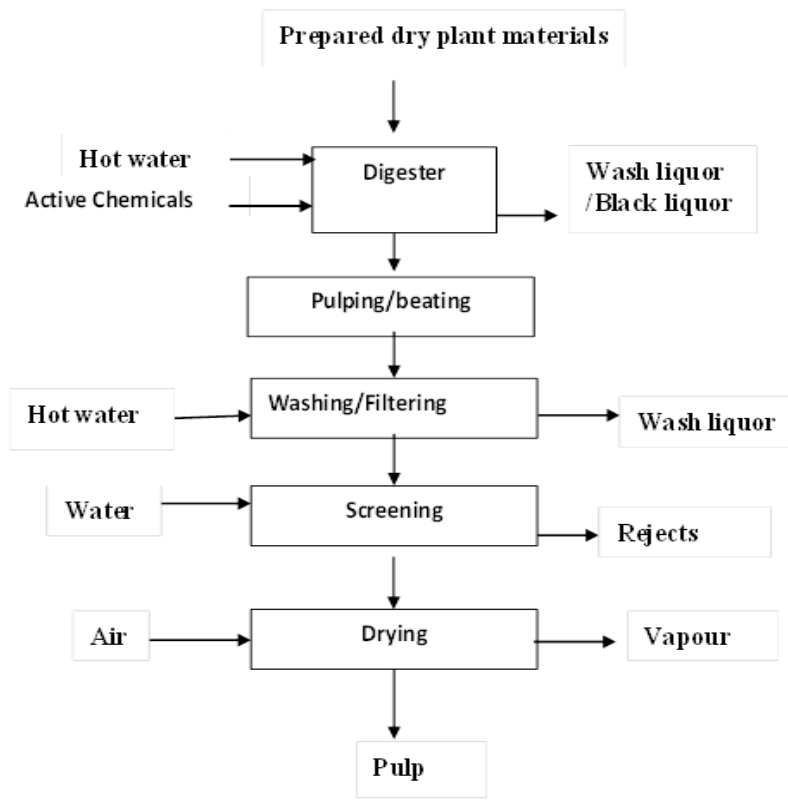

Fig 1 General flow process for pulping [20]

Todate a number of related hybrids of pulping methods that use a combination of chemical, thermal treatment and mechanical treatment are employed in the separation of the fibres. Some common hybrid methods that have been used in pulping both wood and non-wood plant materials include thermo-mechanical pulping (TMP) and chemical thermo mechanical pulping (CTMP).

The general procedure that can be modified for pulping non-wood materials can be summarized in the Fig. 1.

\section{A. Non-Wood Materials that Have Been Researchedupon for Pulp and Paper Production}

Apart from materials such as sugarcane bagasse, bamboo, esparto, kenaf, and agricultural food crop residues which have been tried earlier, of recent there are a number of nonwood materials that have been researched upon for pulp production.The isolated pulp and paper made out of themhave been analyzed and evaluated. Some of those nonwood plant materials which have been investigated are shown in the Table III.

\section{B. Bleaching of Pulp from Non Wood Pulp}

Like wood pulp, non-wood pulp also requires bleaching. Bleaching involves treatment of cellulosic fiber with chemicals as to increase brightness which is achieved by either lignin removal (delignification) or lignin decolonization. Bleaching cleans the pulp of dirt and foreign matter that escaped digestion as well as removing hemicellulose and other extractives. Bleaching of both wood and non-wood pulp has been practiced since early times; sunlight was one of the earliest bleaching agents used. The Japanesealso bleached pulp using water from high mountain streams containing ozone. Later in 1774 Karl Wilhelm 
Scheele discovered chlorine and its bleaching action on vegetable fibers and in 1799, Charles Tennant inverted bleaching powder i.e. calcium hypochlorite. Between 1900 and 1930 multistage bleaching using calcium hypochlorite followed by an alkaline extraction stage and thena repeat of the hypochlorite bleach stage was adopted by the industry.

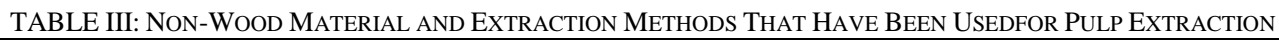

\begin{tabular}{|c|c|c|c|c|c|}
\hline $\mathbf{S} / \mathbf{N}$ & $\begin{array}{l}\text { Non-wood Plant } \\
\text { material }\end{array}$ & $\begin{array}{l}\text { Method(s) of pulp } \\
\text { extraction }\end{array}$ & $\begin{array}{l}\text { Extraction } \\
\text { Conditions employed }\end{array}$ & Findings & Conclusion \\
\hline 1 & Switch grass & $\begin{array}{l}\text { - soda and a } \\
\text { combination of soda } \\
\text { sulphite pulping } \\
\text { - Kraft, soda, and } \\
\text { soda AQ processes }\end{array}$ & $\begin{array}{l}\text { Temperature of } 170^{\circ} \mathrm{c} \\
\text { for } 30 \text { to } 45 \mathrm{~min} \text {, with } \\
\text { liquor to solid ration } \\
\text { of } 6: 1 \text { and varying } \\
\text { ratio of }(\mathrm{NaOH} / \\
\left.\mathrm{Na}_{2} \mathrm{SO}_{3}\right)[22]\end{array}$ & $\begin{array}{l}\text { - High crop yield, high cellulose } \\
\text { content, low extractives and ash } \\
\text { content, high population of short fiber } \\
\text { elements and pulp yields of } 49 \% \text { at a } \\
\text { kappa number of } 13 \text { [21]. } \\
\text { - Fiber length of switch grass, lignin } \\
\text { content, extractablematerials are } \\
\text { similar to that of poplar. }\end{array}$ & $\begin{array}{l}\text { Soda pulp from switch } \\
\text { grass showed excellent } \\
\text { mechanical properties and } \\
\text { showed a great potential } \\
\text { as a reinforcement } \\
\text { component in news print } \\
\text { making [22]. }\end{array}$ \\
\hline 2 & Alfalfa stems & $\begin{array}{l}\text { Soda and soda } \\
\text { anthraquinone } \\
\text { (AQ) pulping, } \\
\text { Kraft and Kraft, } \\
\text { AQ }\end{array}$ & $\begin{array}{l}\text { Temperature of } \\
170 \text { oC, alkali level of } \\
18 \% \text { and sulphidity of } \\
25 \% \text { for } 40 \text { min and a } \\
10: 1 \text { liquid to biomass } \\
\text { ratio. }\end{array}$ & $\begin{array}{l}\text { - Showed length weighed average fiber } \\
\text { length (LWW) of } 0.78 \mathrm{~mm} \text {, very } \\
\text { narrow fiber length distribution, high } \\
\text { fines fiber content, than willow and } \\
\text { hybrid poplar } \\
\text { - Lower fines fiber content of average } \\
\text { fiber length }(0.42 \text { and } 0.48 \mathrm{~mm} \\
\text { LWW). } \\
\text { - Tensile and tear strength higher than } \\
\text { those found for the commercial aspen } \\
\text { pulps. }\end{array}$ & $\begin{array}{l}\text { It can be used in paper } \\
\text { manufacturing if it offers } \\
\text { considerable economic } \\
\text { advantage over } \\
\text { traditional pulp wood } \\
\text { [23]. }\end{array}$ \\
\hline 3 & $\begin{array}{l}\text { Hesperaloe } \\
\text { funifera }\end{array}$ & $\begin{array}{l}\text { Soda- } \\
\text { anthraquinone } \\
\text { pulping }\end{array}$ & $\begin{array}{l}\text { Temperature }(155- \\
\left.180^{\circ} \mathrm{C}\right), \text { cooking } \\
\text { time }(20-60 \mathrm{~min}) \\
\text { and soda } \\
\text { concentration }(5- \\
15 \%) \text { and a } \\
\text { liquid/solid ratio of } \\
8\end{array}$ & $\begin{array}{l}\text { Contains little lignin and abundant } \\
\alpha \text { - cellulose, this, together with the } \\
\text { good morphological characteristics of } \\
\text { its fibres }\end{array}$ & $\begin{array}{l}\text { Potentially highly useful } \\
\text { paper making raw } \\
\text { material [24]. }\end{array}$ \\
\hline 4 & $\begin{array}{l}\text { Pennisetum } \\
\text { purpureum } \\
\text { (elephant grass) }\end{array}$ & - $\quad$ Kraft pulping & $\begin{array}{l}14 \% \text { active alkalis and } \\
20 \% \text { Sulphidity, } \\
\text { temperature of } 160^{\circ} \mathrm{C} \\
\text { for } 60 \text { min }\end{array}$ & $\begin{array}{l}\alpha-\text { Cellulose and lignin content } \\
\text { were } 45.6 \text { and } 17.7 \% \text { respectively, } \\
\text { pulp yield of } 50 \% \text { at kappa number of } \\
9.2 \text { and weight-weighted fibre length } \\
\text { averaged of } 1.32 \mathrm{~mm}\end{array}$ & $\begin{array}{l}\text { Its good characteristics } \\
\text { demonstrate its } \\
\text { suitability for pulp } \\
\text { production[25]. }\end{array}$ \\
\hline
\end{tabular}

In the 1950s, the development in the manufacture of chlorine dioxide and dioxide led to the adoption of the five -stage bleaching sequence that is still used extensively in the industry i.e. 1) Chlorine 2) alkaline extraction 3) chlorine dioxide 4) alkaline extraction 5) Chlorine dioxide. The sequence allowsthe production of very bright pulp with minor losses in fiber length. Bleaching by colonization is achieved by either an oxidizing agents or a reducing agent Chlorine gas, sodium hypochlorite, chlorine dioxide, oxygen gas and hydrogen peroxide are oxidants while sodium hydrosulfite is a reductant. The alkali is used to remove the solubilized lignin from the cellulose. The bleaching is divided into two stages i.e. the pre-bleaching stage and the brightening stage [26]. Of recent biobleaching which utilizes fungal strains such as phanerochaete, chrysosporium and coriolusversicolor has been developed [19].The purpose of prebleaching is to remove as much lignin from pulp as possible to minimize the volume of the more expensive chemicals. Brightening stages that follow prebleaching removes less of lignin but bring out the brilliance of pulp. Therefore bleaching sequence is a combination of the pre-bleaching and brightening stages

\section{The potential of Grasses and Tree Leaves in Pulp Production for Paper Industry}

Although wood from mature trees is still the major source of pulp for paper and contributes about $80 \%$ of the world virgin fiber and accounts for about $35 \%$ of the felled trees, there is a threat of the growing insufficient supply of wood for the growing demand of pulp [27]. The increased rate at which wood is demanded coupled with long period it takes for the trees to mature have resulted in the depletion of mature trees from natural forests. The attempt to establish forest plantations has not solved the problem either. This has resulted into a growing search for alternative fiber sources. Different plant materials produce fibers of different physical properties which influence their utility as pulp, in paper making and related product. Some resources have competing multiple uses and alternative values in society as a result there still a need to search more possible sources of pulp.

Uganda being in the tropics with conducive climate, it is endowed with a number different grasses and trees with leaves which can be potential sources of pulp. These materials are more available and can regenerate a number of times in a year. Taking yield capacity of an acre per given period of time, most of the non-wood materials have higher yield as compared wood production from natural forests. For example switch grass has a yield of $8-12$ oven dry tones (ODT) per hectare per year when the crop is fully established [28] as compared to natural forests managed for wood production of 1-3 Cubic meters per hectare per year [29].

\section{CONCLUSION}

Research findings shows that there is a turning point in 
terms of raw material for the manufacturing of pulp and paper. Agricultural food crop residues, grasses and the shedtree leavesstands potential competitive alternative resource for pulp manufacture due to the fact that they are more available and can readily regenerated. Therefore there is a need to identify more non-wood materials with high potential for pulp and paper production. Todate there is hope in the use of waste grasses and shed tree leaves as raw materials in production of pulp for paper.

\section{REFERENCES}

[1] L. Read, "Fibre supply outlook for North America," Tappi Global fibre supply symposium proceedings, Tappi press, 1995, Atlanta G. A pp. 19

[2] J. T. McClosekey, "What about Non wood?" Tappi Global fibre supply symposium proceedings, 1995, Tappi Press, Atlanta, GA, USA, pp. 95

[3] H. H. Zhen, The invention of paper, Inventions and Discoveries of world, Yuanliu Publishing Co. Taipei Taiwan, 1981, pp. 83-87

[4] M. Jones, "Papyrus a new fuel for the third world," New Scientists, vol. 99, no. 1370 Reed Elsevier London, 1983.

[5] T. H. Tsien and J. Needham, "Science and civilization in China," Chemistry \& Chemistry Technology, vol. 5, Part 1, 1985, Cambridge University, Taipei

[6] A. F. R. Hoernle, "Who was the investor of Rag paper?" The Journal of the Royal Asiatic society of Great Britain and Ireland, revised by Cambridge Journals online, 2011, pp. 63-684.

[7] T. J. Tobin, "The construction of the codex in classic and postclassic period of maya civilization," Westmoreland country college, Youngwood, USA 2001.

[8] J. Atchison and J. Mc Govern, "History of paper and the importance of non-wood plant fiber," Secondary Fibers and Paper Manufacture Series, Joint Text book Atlanta, Tappi press, 1993.

[9] G. van Roetel, "Hemp pulp and paper production," Journal of The International Hemp Association, Amsterdam, Netherland pp. 12ff, 1994

[10] Sjostrom, Wood chemistry, Fundamentals and Applications, Academic press, Orlando, 1993, pp. 293.

[11] R. W. Hurter, Non-wood plant fiber uses in paper making short course notes extracted from "Agricultural residues," Tappi, 2001, Ottawa Ontario Canada.

[12] M. R. Khan and A. Raza, "Content of the fibrous materials of Pakistan," Journal of Chemical society Pakistan, vol. 27, no. 1, 2005, Chemical Society of Pakistan, Karachi, pp.106-108

[13] R. L. Crawford, Lignin biodegradation and transformation, New York: John Wiley and Sons, 1981.

[14] Encyclopaedia Britannica, Cellulose, in Retrieved in January 11th 2008

[15] R. Young and R. M. Rowell, Cellulose structure modification and hydrolysis, Wiley-Interscience, 1986, New York, pp. 379

[16] D. Khemm, B. Heublein, H. P. Fink, and A. Bohn, "Cellulose fascinating Biopolymer and sustainable Raw material," Chem in form, vol. 36, 2005, WILEY-VCH Verlag GmbH \& Co. KGaA, Weinheim, pp. 36.

[17] M. Chabannes, K. Ruel, A. Yoshinaga, B. Chabbert, and A. Jauneau, "In situ analysis in transgenic tobacco reveals a different impact of individual transformation on the spatial patterns of lignin deposition at the cellular and sub cellular levels," Plant journal, vol. 28, 2001, Blackwell science Ltd, Castanet- Tolosan, pp. 271-282.

[18] D. H. Geanadi, Y. Away, Suharyanto, T. Panji, T. Watanabe, and M. Kuwahara, "Pulping of empty fruit bunches of oil palm by white-rot fungi isolated from tropical plantation," in Proc. of 7th International Conference on Biotechnology in pulp and paper industry, B49-52 June 16-19th 1998, Vancouver, Canada, 1998.

[19] K. Masaaki and P. Bambang, "Science for Sustainable utilization of forest resources in the tropics," Midterm Report of JSPS_LIPI Core University Program in the field of wood science during 1996-2000, Wood Research Institute, Kyoto University, Japan, R\&D centre for Applied Physics, LIPI, Indonesia University Putra Malaysia, 2000 ISBN4-9900692-4-4
[20] P. Nagbenjaporn, T. Gaisurapong, P. Srinophakun, and R. Mormanee, "Alternative Chemicals of Handmade paper pulping," Stainable Energy and Environmental technologies, World scientific publishing co. Hong Kong, China, pp. 677, 2000.

[21] K. Goel, R. Eisner, G. Sheron, T. Radiotis, and J. Li, "Switch grass: A potential pulp fibre source," in Proc. the 84th Annual Meeting of the Technical section of the Canadian Pulp and Paper Association, January 1998: Montreal, pp. 109-114.

[22] K. N. Law, B. V. Kokta, and C. B. Mao, "Fibre morphology and soda - sulphite pulping of switch grass," Bioresource Technology, vol. 77, 2001, Elsevier B.V. Minnesota, pp. 1-7.

[23] J. Ai and U. Tschirner, "Fiber length and pulping characteristics of switch grass alfalfa stems, hybrid poplar and willow biomasses," Bioresource Technology, vol. 101, issues 12010, pp. 215 - 221.

[24] R. Sanchez, A. Radriguez, A. Requejo, A. Ferrer, E. Navarro, J. A. Conesa, and L. Jimenez, "Soda pulp and fuel gases synthesis from Hesperaloe funifera," Bioresource Technology, vol. 101, issue 18, Elsevier Ltd Washington DC, pp. 7043-705125, 2010.

[25] I. C. Madakadze, T. M. Masamvu, T. Radiotis, J. Li, and D. L. Smith, "Evaluation of pulp and paper making characteristics of elephant grass (pennistetumpurpureumschum) and Switch grass (panicum virgatum L)," African Journal of Environmental science and Technology, vol. 4, no. 7, pp. 465-470, July 2010

[26] K. Saijnkari and Pahkala, "N0n-wood plants as raw material for pulp and paper," Academic Dissertation on Plant production Research, University of Helsinki and MTT Agrifood Research Finland2001.

[27] M. Sam, Paper Chase Ecology communication Inc., Internet Archive, Web. 20 Jan 2011

[28] P. Girouard and R. Samson, "The potential role of perennial grasses in the pulp and paper industry," Resource Efficient Agricultural Production (REAP) Report, Canada.2000.

[29] Wikimedia Foundation, Inc. Industrial Plantations, Wikipedia, Free encyclopedia, 29th April 2012 at 18:50

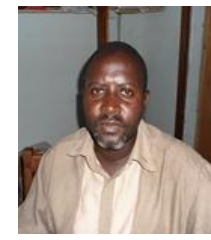

Kamoga Omar Lwako M. was born on $03^{\text {rd }}$ June 1971 in Mukono District Uganda, He completed MSc (Chem.) in 2000, PGDE in 1998 and BSc (Ind Chem.)in 1996, all from Makerere University.

Currently he is $\mathrm{PhD}$ Student at Makerere University, Department of Mechanical Engineering and a Lecturer at Busitema University. He has interest in materials science technology more especially in paper technology. He is currently researching on extraction pulp from non-wood materials for paper industry.

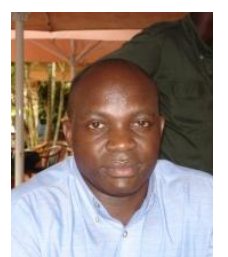

John Baptist Kirabira was born on November 26 , 1971, Kirabira completed his PhD in June 2005 and his Licentiate degree at KTH.

$\mathrm{He}$ is currently a senior lecturer in the Department of Mechanical Engineering, Makerere University. He has interest in engineering materials and minerals and $\mathrm{PhD}$ theses were in materials science and Engineering. Recently, he has been working on the viability of application of Mutaka kaolin for paper filling and coating, in conjunction with STFI Pack-forsk and $\mathrm{KTH}$. Besides, he has been involved in various engineering and management consultancies with both local and international organizations. $\mathrm{He}$ is a registered Engineer and a corporate member Uganda Institution of Professional Engineers (UIPE). He has published widely locally, regionally and internationally in the areas of materials science and engineering.

Joseph K. Byaruhanga was born in Uganda. He holds a B.Sc.(Eng), PhD, MUIPE, R. Eng. He is a senior Lecturer Department of Mechanical Engineering Makerere University. Also he is the General Manager of Uganda Gatsby Trust, a small scale enterprises project. 